\title{
Growth and metabolic responses of orange spotted grouper Epinephelus coioides (Hamilton, 1822) fingerlings at different salinity regimes
}

\author{
BIJI XAVIER, SEKAR MEGARAJAN, RITESH RANJAN, BISWAJIT DASH*, NARASIMHULU \\ SADHU, PONNAGANTI SIVA AND SHUBHADEEP GHOSH \\ Regional Centre of ICAR-Central Marine Fisheries Research Institute, Visakhapatnam - 530 003. Andhra Pradesh, India \\ "Puri Field Centre of ICAR-Central Marine Fisheries Research Institute, Puri - 752 002, Odisha, India \\ e-mail: bijicmfri@gmail.com
}

\begin{abstract}
A feeding trial was conducted for 60 days to delineate the effect of different salinities on growth and metabolic responses in fingerlings of orange spotted grouper Epinephelus coioides (Hamilton, 1822). The grouper fingerlings ( $\mathrm{N}=1050 ; 2.0 \pm 0.01 \mathrm{~g}$ ) were distributed equally into seven treatments of varying salinities viz., $5 \pm 1 \%$ o $\left(\mathrm{T}_{1}\right), 10 \pm 1 \%$ o $\left(\mathrm{T}_{2}\right), 15 \pm 1 \%$ o $\left(\mathrm{T}_{3}\right), 20 \pm 1 \%$ o $\left(\mathrm{T}_{4}\right)$, $25 \pm 1 \% 0\left(\mathrm{~T}_{5}\right), 30 \pm 1 \% 0\left(\mathrm{~T}_{6}\right)$ and $35 \pm 1 \%$ o $\left(\mathrm{T}_{7}\right)$, in triplicates. Fingerlings were fed with commercial diet containing $45 \%$ crude protein and $10 \%$ lipid. Results from the experiment concluded that growth performance of fingerlings of $\mathrm{T}_{4}$ group was better with minimum metabolic enzyme activity. The liver glycogen was significantly lower $(\mathrm{p}<0.05)$ in $\mathrm{T}_{4}$ group. Oxygen consumption rate (OCR) was recorded maximum at $15 \pm 1 \%$ and was significantly reduced for the fingerlings maintained at high salinity $(\mathrm{p}<0.05)$ from $20 \pm 1$ to $35 \pm 1 \%$. Orange spotted grouper fingerlings maintained at salinity of $20 \pm 1 \%$ confirmed that, the animal spent less metabolic energy for maintaining the ionic balance at this optimum salinity compared to other salinities and it was reflected in better growth performance with minimum OCR and metabolic enzyme activities.
\end{abstract}

Keywords: Glycogen, Metabolic enzyme, Orange spotted grouper, Oxygen consumption

\section{Introduction}

Aquaculture is developing at a very rapid pace with species diversification using various culture practices. Well-being of fish, disease resistance and availability of good water quality are of paramount importance for achieving good growth (Fazio et al., 2013). Culture environment with different water quality parameters and feeding play a major role and these parameters can be controlled to some extent with human interventions for increasing growth of the targeted fish in culture. Among the different environmental factors, salinity is the most important factor, which is directly influencing fish growth along with temperature and oxygen (Mommsen, 1998). Optimum salinity determines the survival, growth and production of the cultured marine fish species. Fishes have different ranges of salinity tolerance, with euryhaline fish being capable of tolerating a wide range of salinities as they have the ability to synthesise new salt transporting proteins while moving from salt to freshwater and vice versa (Kidder III et al., 2006). In this type of fish species, energy will be used primarily for osmoregulation and that energy may not be available for growth. Freshwater or marine fish uses energy through osmoregulation to hold ions in or off their bodies (Kucuk et al., 2013). Since osmoregulation is an energy demanding process, which is met from the food ingested, growth results from the differences of food ingested and metabolic energy used (Jobbling, 1994). At optimum salinity regimes, energy is saved for improving the growth rate of the fish (Webster and Dill, 2006). Optimum salinity for growth and metabolic rate is influenced by other factors, including species and developmental status of the fishes (Morgan and Iwama, 1991).

Orange spotted grouper Epinephelus coioides (Hamilton, 1822) is commercially and economically an important marine tropical fish cultured in south-east Asian countries. Extensive culture of groupers is practiced in sea cages and coastal ponds, but different growth rates in the fish have been reported from different culture systems having variations in water salinities. Groupers are hardy species and tolerate wide ranges of salinities. However, identifying optimum salinity range may help the species to attain maximum growth rate on the cost of minimum use of energy for osmoregulation and effective feed utilisation (Blaber, 1997). However, it has also been reported in different studies that any changes in salinity will lead to imbalance of the internal stability (homeostasis) leading to various kinds of stress in the animal (Enayati et al., 2013) and eventually reduced growth rate. In this background, the present study was carried out with an aim 
to determine optimum salinity for better growth and to understand the effects of various salinities on the growth and metabolic responses of hatchery produced grouper (E. coioides) fingerlings.

\section{Materials and methods}

\section{Experimental design}

Fingerlings of orange spotted grouper (E. coioides) produced in the marine hatchery at Visakhapatnam Regional Centre of ICAR-Central Marine Fisheries Research Institute (ICAR-CMFRI), Visakhapatnam, India were used for the study. One thousand and fifty fingerlings $(2.0 \pm 0.01 \mathrm{~g})$ were equally distributed into seven treatment groups (in triplicates) in 1001 of seawater of varying salinities viz., $5 \pm 1 \%$ o $\left(\mathrm{T}_{1}\right), 10 \pm 1 \%$ o $\left(\mathrm{T}_{2}\right), 15 \pm 1 \%$ o $\left(\mathrm{T}_{3}\right)$, $20 \pm 1 \%$ o $\left(\mathrm{T}_{4}\right), 25 \pm 1 \%$ o $\left(\mathrm{T}_{5}\right), 30 \pm 1 \%$ o $\left(\mathrm{T}_{6}\right)$ and $35 \pm 1 \%$ o $\left(\mathrm{T}_{7}\right)$. The fishes maintained at $35 \pm 1 \%\left(\mathrm{~T}_{7}\right)$ was considered as control, as this is the salinity commonly used for hatchery operation for this species and which is also in close proximity to the salinity in its natural habitat in the wild. Experimental salinities were arrived at by mixing spring water with seawater drawn from the sea. The required experimental salinity range (35 to $5 \%$ ) was prepared by thorough mixing and vigorous aeration of seawater and required quantity of spring water. In order to acclimatise the fingerlings, the salinity was reduced by five units in a day and then the fingerlings maintained at that reduced salinity for three days till they showed normal behaviour and good feed acceptance. Same process was followed to bring the water to the desired salinity and acclimatise the fish for further experimentation.

Water quality parameters like temperature, $\mathrm{pH}$, dissolved oxygen, free $\mathrm{CO}_{2}$ and alkalinity, total ammonia nitrogen (TAN) and nitrite nitrogen $\left(\mathrm{NO}_{2}-\mathrm{N}\right)$ were measured using a multi-parameter device (YSI, model 55-12FT, YSI Corporation, USA) and salinity was measured with a refractometer (Atago S/Mill-E, Atago Co. Ltd, Tokyo, Japan)

The fingerlings were fed with commercial diet containing 45\% crude protein and 10\% lipid (Growel Pvt. Ltd., India). The individual daily consumption of feed was obtained by dividing the total consumption of feed by each fish and the number of days of the experiment. Fingerlings of each treatment were weighed every 15 days using an electronic balance. Feeding was stopped $24 \mathrm{~h}$ before fish weight measurement. The experiment was conducted for a period of 60 days.

\section{Survival and growth parameters}

Fish survival was expressed as percentage of total fish tested and was calculated as:
$\mathrm{S}=\left[\left(\mathrm{N}_{\mathrm{i}}-\mathrm{N}_{\mathrm{f}}\right) / \mathrm{N}_{\mathrm{i}}\right] \times 100$; where $\mathrm{N}_{\mathrm{i}}$ is the number of fish stocked in the tank at the beginning of the experiment while $\mathrm{N}_{\mathrm{f}}$ corresponds to the number of surviving fish after 60 days of experiment.

Weight gain (WG) was expressed in percentage and calculated according to the following equation:

Weight gain $\%=\left[\left(\mathrm{W}_{\mathrm{f}}-\mathrm{W}_{\mathrm{i}}\right) / \mathrm{W}_{\mathrm{i}}\right] \times 100$; where $\mathrm{W}_{\mathrm{f}}$ and $\mathrm{W}_{\mathrm{i}}$ are fish body weights $(\mathrm{g})$ at the end and beginning of the experiment respectively.

Specific growth rate (SGR) was expressed as percentage and was calculated as:

$\mathrm{SGR}=\left[\left(\ln \mathrm{W}_{\mathrm{f}}-\ln \mathrm{W}_{\mathrm{i}}\right) / \mathrm{NOD}\right] \times 100 ;$ where $\mathrm{W}_{\mathrm{f}}$ and $\mathrm{W}_{\mathrm{i}}$ are fish body weights at the end and beginning of the experiment respectively and NOD is number of days.

Food conversion ratio (FCR) was calculated as TDFI/ WWG; where TDFI is total dry feed intake $(\mathrm{g})$ and WWG is wet weight gain $(\mathrm{g})$.

\section{Whole body oxygen consumption}

To estimate the oxygen consumption rate, 10 fingerlings (average length $97.83 \pm 1.07 \mathrm{~mm}$ and average weight $8.63 \pm 0.16 \mathrm{~g}$ ) from all the experimental salinities were removed and placed separately in buckets with 51 water of respective salinities, which were aerated for $6 \mathrm{~h}$ prior to the introduction of fingerlings. Water quality parameters were maintained uniformly. Dissolved oxygen levels were measured at intervals of every $30 \mathrm{~min}$ for a total duration of $3 \mathrm{~h}$. The oxygen consumption was expressed as $\mathrm{ml} \mathrm{l}^{-1} \mathrm{~h}^{-1}$ and calculated as:

$$
\mathrm{OCR}=\left(\mathrm{DO}_{\mathrm{i}}-\mathrm{DO}_{\mathrm{f}}\right) / \mathrm{T}
$$

where, $\mathrm{DO}_{\mathrm{i}}$ is initial $\mathrm{DO}, \mathrm{DO}_{\mathrm{f}}$ is final $\mathrm{DO}$ and $\mathrm{T}$ is time.

\section{Tissue sample collection and biochemical analysis}

On completion of the experiment, two fish from each replicate from all treatments were sampled $(n=6)$. The fishes were anaesthetised with phenoxy ethanol $\left(50 \mu \mathrm{l}^{-1}\right)$ and tissue samples (liver and muscle) were collected

Glycogen from liver and muscle was estimated by the colourimetric method described by Hassid and Abraham (1957). Tissue was digested in 30\% potassium hydroxide (KOH) by keeping in boiling water bath for $20 \mathrm{~min}$. Digested tissue was cooled and then, $5 \mathrm{ml}$ of $95 \%$ ethanol was added to precipitate the whole content by centrifugation and the process was repeated twice. The glycogen precipitate was then dissolved in distilled water and this solution was used to estimate the quantity of glycogen.

Tissue homogenate was prepared in chilled sucrose solution $(0.25 \mathrm{M})$ for tissue enzyme analyses. 
Aspartate amino transferase (AST) activity was assayed as describedbyWootton(1964), wherethesubstratecomprising of D, L- aspartic acid ( $0.2 \mathrm{M})$ and $\alpha$-ketoglutarate $(2 \mathrm{mM})$ dissolved in phosphate buffer $(0.05 \mathrm{M} ; \mathrm{pH}$ 7.4) was prepared and added into test $(\mathrm{T})$ and control $(\mathrm{C})$ tubes. The reaction was started by adding $0.1 \mathrm{ml}$ of homogenate into the $\mathrm{T}$ tubes alone. Thereafter the assay mixture was incubated at $37^{\circ} \mathrm{C}$ for $60 \mathrm{~min}$ and then terminated by adding $0.5 \mathrm{ml}$ of $1 \mathrm{mM} \mathrm{2,4}$ dinitrophenyl hydrazine (DNPH). In the $\mathrm{C}$ tubes, the enzyme source (homogenate) was added after adding DNPH solution. The tubes were kept at room temperature for $20 \mathrm{~min}$ with occasional shaking. Then $5 \mathrm{ml}$ of $\mathrm{NaOH}(0.4 \mathrm{~N})$ was added and thoroughly mixed. After $10 \mathrm{~min}$, the optical density (OD) was recorded at $540 \mathrm{~nm}$. Alanine amino transferase (ALT) activity was assayed as described by Wootton (1964). ALT was estimated with the similar process of AST using different substrate consisting of D, L- alanine (0.2 M ) and $\alpha$-ketoglutarate $(2 \mathrm{mM})$ in phosphate buffer $(0.05 \mathrm{M}$; $\mathrm{pH}$ 7.4). Lactate dehydrogenase (LDH) activity was assayed as per the method of Wroblewski and Ladue (1955) using sodium pyruvate as substrate. The OD was recorded at $340 \mathrm{~nm}$ at $30 \mathrm{~s}$ interval for $3 \mathrm{~min}$. The enzymatic activity was expressed as units $\mathrm{mg}$ protein ${ }^{-1} \mathrm{~min}^{-1}$ at $25^{\circ} \mathrm{C}$ where 1 unit was equal to $\Delta 0.01 \mathrm{OD} \mathrm{min}^{-1}$.

\section{Blood collection and serum biochemical analysis}

At the end of the feeding trial, fishes were anaesthetised and blood samples were collected from the caudal region using disposable syringe with 21 gauge hypodermic needle and was transferred to Eppendorf tubes. Blood sample was thoroughly mixed in a gentle fashion and kept for serum separation. The serum was collected by centrifuging the sample in a micro-centrifuge at $5000 \mathrm{rpm}$ for $10 \mathrm{~min}$ and was used for the analysis of various serum parameters. Total protein, albumin, glucose and alkaline phosphatase were estimated using a commercial kit (Erba Diagnostics, TransAsia Bio Medicals Ltd., Germany).

\section{Data analysis}

Data were analysed by ANOVA followed by Tukey's test. Results were expressed as mean \pm standard error. The significance level adopted was $95 \%(\mathrm{p}<0.05)$. Statistical analyses were carried out using SPSS version 16.0 (SPSS for Windows, Version 16.0. SPSS Inc., Chicago, USA).

\section{Results}

Results from our study revealed that water temperature and $\mathrm{NH}_{3}-\mathrm{N}$ concentration were similar for all treatment groups over the experimental period $(\mathrm{p}>0.05)$. Mean values were $28.5 \pm 0.1^{\circ} \mathrm{C}$ and $0.02 \pm 0.001 \mathrm{mg}^{-1}$ respectively, while dissolved oxygen remained above $90 \%$ saturation $\left(7.6 \pm 0.02 \mathrm{mg} \mathrm{l}^{-1}\right)$. Mean $\mathrm{pH}$ recorded was $8.2 \pm 0.02$, which was not significantly $(\mathrm{p}>0.05)$ different among the treatments.

Body weight of the fingerlings maintained at varying salinity was recorded at biweekly intervals (Fig. 1). There was $100 \%$ survival in all treatments $(p>0.05)$, even though the fishes were maintained in various salinity regimes.

The growth parameters recorded for the grouper fingerlings at different salinity regimes are presented in Table 1.The observed $\mathrm{WG} \%$ was significantly higher in $\mathrm{T}_{4}$ (407.26 \pm 2.26$)$ and lower in $\mathrm{T}_{1}(264.50 \pm 0.50)$. However, treatments $\mathrm{T}_{3}$ and $\mathrm{T}_{6}$ showed similar performance $(\mathrm{p}>0.05)$ and significantly differed from the rest of the treatments. Significantly higher $(\mathrm{p}<0.05)$ SGR was

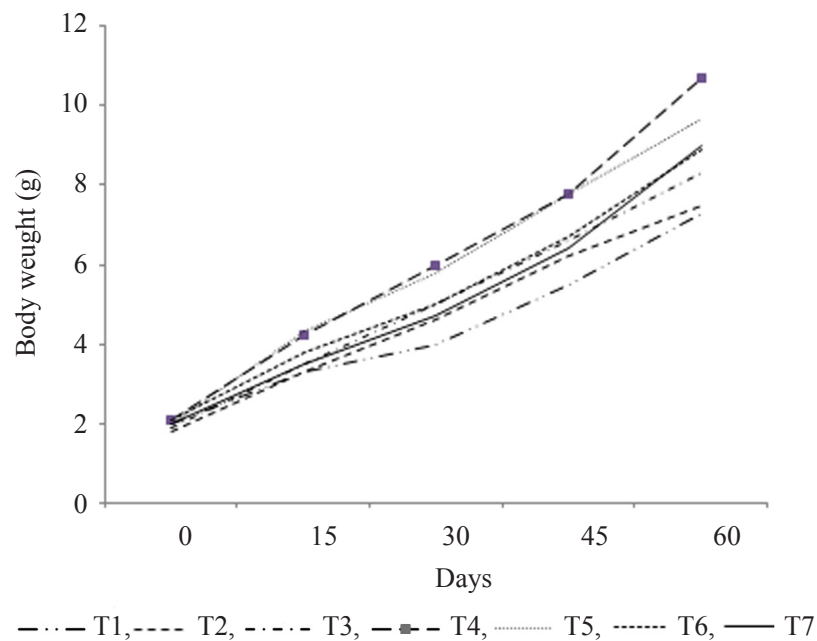

Fig. 1. Body weight of fingerlings maintained at different salinities

Table 1. Effect of salinity on the growth performance $(m e a n \pm S E)$ of grouper fingerlings on termination of the experiment

\begin{tabular}{llllll}
\hline Treatments & Initial weight $(\mathrm{g})$ & Final weight $(\mathrm{g})$ & Weight gain $\%$ & SGR & FCR \\
\hline $\mathrm{T}_{1}$ & $2.0 \pm 0.01$ & $7.33^{\mathrm{a}} \pm 0.03$ & $264.50^{\mathrm{a}} \pm 0.50$ & $1.27^{\mathrm{a}} \pm 0.03$ & $1.73^{\mathrm{d}} \pm 0.01$ \\
$\mathrm{~T}_{2}$ & $2.0 \pm 0.01$ & $7.51^{\mathrm{a}} \pm 0.01$ & $315.34^{\mathrm{b}} \pm 1.34$ & $1.42^{\mathrm{b}} \pm 0.02$ & $1.71^{\mathrm{d}} \pm 0.05$ \\
$\mathrm{~T}_{3}$ & $2.0 \pm 0.01$ & $8.27^{\mathrm{b}} \pm 0.02$ & $334.42^{\mathrm{c}} \pm 2.42$ & $1.44^{\mathrm{b}} \pm 0.03$ & $1.63^{\mathrm{c}} \pm 0.01$ \\
$\mathrm{~T}_{4}$ & $2.1 \pm 0.01$ & $10.75^{\mathrm{d}} \pm 0.05$ & $407.26^{\mathrm{f}} \pm 2.26$ & $1.63^{\mathrm{c}} \pm 0.001$ & $1.43^{\mathrm{a}} \pm 0.05$ \\
$\mathrm{~T}_{5}$ & $2.1 \pm 0.01$ & $9.65^{\mathrm{c}} \pm 0.05$ & $382.50^{\mathrm{e}} \pm 2.50$ & $1.55^{\mathrm{b}} \pm 0.03$ & $1.50^{\mathrm{b}} \pm 0.01$ \\
$\mathrm{~T}_{6}$ & $2.0 \pm 0.03$ & $8.85^{\mathrm{b}} \pm 0.05$ & $331.02^{\mathrm{c}} \pm 1.02$ & $1.42^{\mathrm{b}} \pm 0.04$ & $1.57^{\mathrm{b}} \pm 0.01$ \\
$\mathrm{~T}_{7}$ & $2.0 \pm 0.01$ & $9.02^{\mathrm{c}} \pm 0.001$ & $351.00^{\mathrm{d}} \pm 1.00$ & $1.55^{\mathrm{b}} \pm 0.05$ & $1.54^{\mathrm{b}} \pm 0.05$ \\
\hline
\end{tabular}

Means bearings different superscripts in the columns differ significantly (Tukey's test; $\mathrm{p}<0.05$ ) 
recorded in the treatment $\mathrm{T}_{4}(1.63 \pm 0.001)$ and lowest was in $\mathrm{T}_{1}(1.27 \pm 0.03)$. Lowest FCR $(1.43 \pm 0.05)$ was observed for treatment $T_{4}$ and higher for $T_{1}(1.73 \pm 0.01)$ followed by $\mathrm{T}_{3}$. Observed FCR did not show significant differences between other treatments $\left(\mathrm{T}_{5}, \mathrm{~T}_{6}\right.$ and $\left.\mathrm{T}_{7}\right)$.

Oxygen consumption rate (OCR) of fingerlings exposed to various salinity regimes is depicted in Fig. 2. OCR was increasing with increase in salinity with maximum $\left(1.53 \mathrm{ml} \mathrm{l}^{-1} \mathrm{~h}^{-1}\right)$ value recorded in $\mathrm{T}_{3}(\mathrm{p}<0.05)$. It was significantly $(\mathrm{p}<0.05)$ reduced for the fingerlings maintained at high salinity from $20 \pm 1$ to $35 \pm 1 \%$ o.

Liver glycogen of grouper fingerlings reared at various salinities is depicted in Fig. 3. Liver glycogen was significantly $(\mathrm{p}<0.05)$ decreasing with increasing salinity up to $20 \pm 1 \%$ and thereafter it was found increasing. Highest values were recorded in fingerlings of $T_{1}$ and lowest liver glycogen was recorded in fingerlings of $\mathrm{T}_{4}$.

$\mathrm{T}_{4}$ group recorded highest AST activity in both muscle and liver (Table 2). In the muscle, significantly $(p<0.05)$ higher and lower activities of AST were recorded in fingerlings of $\mathrm{T}_{2}$ and $\mathrm{T}_{4}$ respectively. In liver, fingerlings of $\mathrm{T}_{4}$ registered significantly lower $(\mathrm{p}<0.05)$ AST activity, when compared to the rest of the groups. Highest AST activity in liver was observed in fingerlings of $\mathrm{T}_{1}$, which was not significantly different from fingerlings of $T_{6}$ and $\mathrm{T}_{7}$ groups. There was no significant difference in liver AST activity among the fingerlings of $T_{2}, T_{3}$ and $T_{5}$ groups $(\mathrm{p}>0.05)$.

ALT activity in muscle and liver followed an increasing trend at higher and lower salinities (Table 2) with lowest activity in $\mathrm{T}_{4}$. Significantly higher ALT activity was observed in both muscle and liver tissues of fingerlings maintained in $\mathrm{T}_{1}$ group $(\mathrm{p}<0.05)$ and lower activity was observed in fingerlings of $T_{4}$ followed by $T_{5}$, $\mathrm{T}_{7}$ and $\mathrm{T}_{6}$.

Significantly higher LDH activity $(p<0.05)$ in muscle was registered in $T_{1}$ and lower activity was recorded in $T_{4}$ which was not significantly different from fingerlings of $\mathrm{T}_{5}(\mathrm{p}>0.05)$. A decreasing trend was observed in muscle LDH activity in fingerlings with increase in salinity of $\mathrm{T}_{1}$ to $\mathrm{T}_{3}$. In liver, decreasing trend in LDH activity was observed in fingerlings of $\mathrm{T}_{1}, \mathrm{~T}_{2} \mathrm{~T}_{3}$ and $\mathrm{T}_{4}$ groups. Highest and lowest LDH activity was recorded in fingerlings of $\mathrm{T}_{1}$ and $\mathrm{T}_{4}$ respectively (Table 2 ).

Table 2. Effect of salinity on aspartate amino transferase (AST), alanine amino transferase (ALT) and lactate dehydrogenase (LDH) activity in muscle and liver of grouper fingerlings on termination of the experiment

\begin{tabular}{llllllll}
\hline \multirow{2}{*}{ Treatments } & \multicolumn{2}{c}{$\left.\begin{array}{c}\text { AST }(\mathrm{n} \mathrm{mol} \mathrm{sodium} \mathrm{pyruvate} \\
\text { released } \text { min }^{-1} \text { mg protein }\end{array}\right)$}
\end{tabular}

Means bearing different superscripts in the columns differ significantly (Tukey's test; $\mathrm{p}<0.05$ )

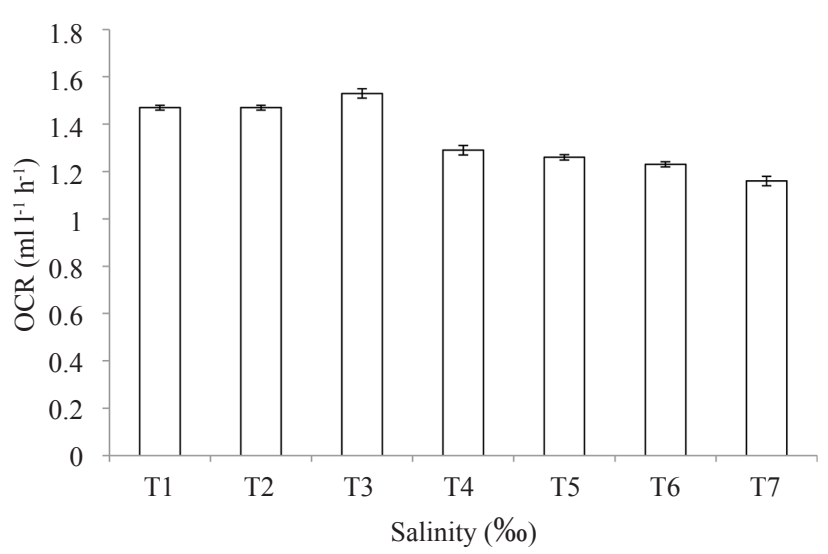

Fig. 2. Oxygen consumption rate (OCR) in grouper fingerlings exposed to various salinity regimes

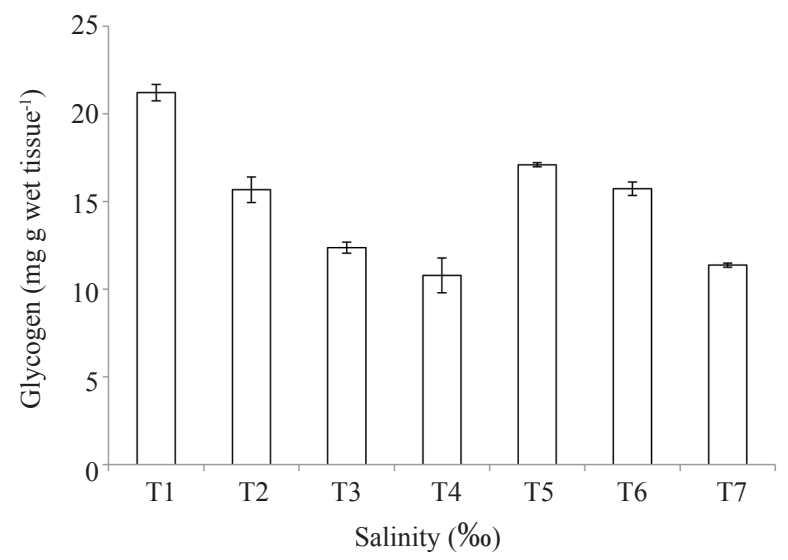

Fig. 3. Liver glycogen in grouper fingerlings exposed to various salinity regimes 
Fingerlings of $\mathrm{T}_{1}$ recorded highest serum total protein content followed by $\mathrm{T}_{6}$ group and the lowest was observed in fingerlings of $\mathrm{T}_{2}$, which was not significantly different from fingerlings of $\mathrm{T}_{3}(\mathrm{p}>0.05)$. Fingerlings of $\mathrm{T}_{4}$ and $\mathrm{T}_{7}$ groups expressed similar total protein content at the end of the experiment (Table 3). Significantly highest serum albumin content was registered in fingerlings of $T_{1}$ followed by fingerlings of $\mathrm{T}_{5}$ which was not significantly different from fingerlings of $\mathrm{T}_{6}$ and $\mathrm{T}_{7}$ groups $(\mathrm{p}>0.05)$. Fingerlings of $\mathrm{T}_{3}$ showed significantly lower serum albumin content $(\mathrm{p}<0.05)$. Serum globulin content was highest in fingerlings of $\mathrm{T}_{1}(\mathrm{p}<0.05)$ followed by fingerlings of $\mathrm{T}_{6}$ and lowest in fingerlings of $\mathrm{T}_{7}$. The serum globulin concentration was similar in fingerlings of $\mathrm{T}_{2}, \mathrm{~T}_{3}, \mathrm{~T}_{4}$ and $\mathrm{T}_{5}$ groups $(\mathrm{p}>0.05)$. Significantly higher serum glucose was recorded in fingerlings of $\mathrm{T}_{1}(\mathrm{p}<0.05)$ followed by $\mathrm{T}_{4}$. Fingerlings of $T_{2}$ showed lowest glucose, however, it was not significantly different from fingerlings of $T_{3}, T_{5}$ and $T_{7}$ groups $(p>0.05)$. Serum alkaline phosphatase was significantly higher in fingerlings of $\mathrm{T}_{6}$ which was not significantly different from $\mathrm{T}_{4}(\mathrm{p}>0.05)$. Lowest activity was recorded in fingerlings of $\mathrm{T}_{7}$ followed by fingerlings of $\mathrm{T}_{2}$.

\section{Discussion}

In the present study, orange spotted grouper fingerlings were reared at various salinities ranging from $5 \pm 1$ to $35 \pm 1 \%$. The effect of various salinities on survival, growth and selected biochemical parameters of the grouper fingerlings were studied. Fish maintained in hypo or hyper-osmotic environments demand additional energy requirements for osmoregulation which will hamper growth when compared to those kept at an isosmotic environment (Boeuf and Payan, 2001). This was also studied in juveniles of fat snook (Tsuzuki et al., 2007) and wedge sole (Herrera et al., 2009). It has been shown that salinity changes affected the oxygen consumption, ammonium excretion, osmoregulation and $\mathrm{Na}+/ \mathrm{K}+$-ATPase expression in the bullseye puffer (PerezRobles et al., 2012). The energy demand for metabolism may vary with fish species and is associated with the interaction between osmoregulatory mechanisms with other physiological processes (Jobling, 1994; Imsland et al., 2002) and fish ecology (O'Neill et al., 2011).

Results from our study revealed that water temperature and $\mathrm{NH}_{3}-\mathrm{N}$ concentration were similar to all treatment groups over the experimental period. There was $100 \%$ survival in all treatments, even though the fishes were maintained in various salinity regimes. Being a euryhaline species, orange spotted grouper fingerlings efficiently tolerated the salinity variations.

Final body weight and SGR were significantly affected by water salinity. Salinity had significant effect on the growth parameters (WG, SGR and FCR) of orange spotted grouper fingerlings. There was significantly higher $(\mathrm{p}<0.05)$ weight gain $\%$ and $\mathrm{SGR}$ in $\mathrm{T}_{4}$ when compared to all other treatments. Same group of fingerlings $\left(T_{4}\right)$ performed better with FCR of 1.43. This might have resulted from the environment in which the grouper fingerlings were reared with optimum salinity $\left(\mathrm{T}_{4}\right)$, which was probably isotonic with body fluids of the animal. Our results are also in agreement with the reports in Mozambique tilapia (Oreochromis mossambicus) that optimum growth is achieved at a salinity which is isotonic with the body fluids of the animal (Morgan et al., 1997). The isotonic salinity affected growth, metabolism and ion regulation in juveniles of trout and salmon (Morgan and Iwama, 1991). In our study, orange spotted grouper being a euryhaline species, registered highest growth performance with salinity of $20 \pm 1 \%$. It has also been reported that marine fishes have higher growth rate at lower water salinity levels, whereas freshwater fishes have higher growth rate at higher salinity levels (Boeuf and Payan, 2001).

Growth performance of grouper fingerlings at high salinities $(25 \pm 1 \%, \quad 30 \pm 1 \%$ and $35 \pm 1 \%$ ) was less compared to the rest of the treatment groups. The increased salinity might have reduced the appetite of the fingerlings which resulted in reduced growth performance. This is also in agreement with the report that the increase in salinity resulted in decreased growth performance of juvenile turbot (Scophthalmus maximus) due to decreased feed intake (Imsland et al., 2002). In juvenile rainbow and

Table 3. Effect of salinity on serum biochemical parameters (mean $\pm \mathrm{SE}$ ) of grouper fingerlings on termination of the experiment

\begin{tabular}{|c|c|c|c|c|c|}
\hline Treatments & Serum total protein $\left(\mathrm{g} \mathrm{dl}^{-1}\right)$ & Serum albumin $\left(\mathrm{g} \mathrm{dl}^{-1}\right)$ & Serum globulin $\left(\mathrm{g} \mathrm{dl}^{-1}\right)$ & Serum glucose $\left(\mathrm{mg} \mathrm{dl}^{-1}\right)$ & Alkaline phosphatase (IU ${ }^{1-1}$ ) \\
\hline$\overline{\mathrm{T}_{1}}$ & $6.43^{\mathrm{d}} \pm 0.02$ & $1.46^{\mathrm{d}} \pm 0.01$ & $4.95^{\mathrm{c}} \pm 0.01$ & $38.90^{\mathrm{b}} \pm 0.47$ & $523.91^{\mathrm{c}} \pm 2.68$ \\
\hline $\mathrm{T}_{2}$ & $4.72^{\mathrm{a}} \pm 0.01$ & $1.13^{b} \pm 0.01$ & $3.58^{\mathrm{a}} \pm 0.01$ & $30.04^{\mathrm{a}} \pm 0.09$ & $373.29^{b} \pm 0.75$ \\
\hline $\mathrm{T}_{3}^{2}$ & $4.69^{\mathrm{a}} \pm 0.01$ & $1.03^{\mathrm{a}} \pm 0.01$ & $3.67^{\mathrm{ab}} \pm 0.02$ & $31.07^{\mathrm{a}} \pm 0.81$ & $605.48^{\mathrm{d}} \pm 0.77$ \\
\hline $\mathrm{T}_{4}^{3}$ & $4.81^{\mathrm{ab}} \pm 0.03$ & $1.15^{\mathrm{b}} \pm 0.01$ & $3.65^{\mathrm{ab}} \pm 0.04$ & $36.97^{\mathrm{b}} \pm 0.72$ & $694.04^{\mathrm{e}} \pm 0.19$ \\
\hline $\mathrm{T}_{5}^{4}$ & $4.92^{b} \pm 0.04$ & $1.24^{\mathrm{c}} \pm 0.01$ & $3.68^{\mathrm{ab}} \pm 0.03$ & $30.66^{\mathrm{a}} \pm 0.51$ & $537.91^{\mathrm{c}} \pm 11.33$ \\
\hline $\mathrm{T}_{6}^{5}$ & $5.08^{c} \pm 0.02$ & $1.26^{\mathrm{c}} \pm 0.01$ & $3.76^{b} \pm 0.04$ & $31.91^{\mathrm{a}} \pm 0.46$ & $710.65^{\mathrm{e}} \pm 0.65$ \\
\hline $\mathrm{T}_{7}^{0}$ & $4.82^{\mathrm{ab}} \pm 0.02$ & $1.25^{\mathrm{c}} \pm 0.01$ & $3.56^{\mathrm{a}} \pm 0.03$ & $30.44^{\mathrm{a}} \pm 0.01$ & $337.12^{\mathrm{a}} \pm 2.00$ \\
\hline
\end{tabular}

Means bearing different superscripts in the columns differ significantly (Tukey's test; $\mathrm{p}<0.05$ ) 
steelhead trout (Oncorhynchus mykiss) and fall Chinook salmon (Oncorhynchus tshawytscha), it has been reported that in high salinity, energy is used for osmoregulation in order to maintain the ionic balance in the body fluids which resulted in poor growth of the animal (Morgan, 1991). In our study, the fingerlings maintained at $\mathrm{T}_{4}$ performed better in terms of growth and hence it may be considered as optimum salinity for growth of orange spotted grouper fingerlings. Under optimum salinity, the energy utilised for osmoregulation is minimal and maximum energy is utilised for growth of the fish (Webster and Dill, 2006).

It was observed that grouper fingerlings reared at lower salinities ( $5 \pm 1-15 \pm 1 \%$ ) also performed poorly in terms of growth parameters. This may be due to the high oxygen consumption at lower salinity which demands more metabolic energy resulting in poor growth of the animal. It is also possible that lower growth observed in lower salinity was caused by an increased energy demand for osmoregulation and maintenance of other physiological processes. Our results are also in agreement with the report that any salinity range, which is not optimum, will increase the energy cost for osmoregulation resulting in poor growth performance of the fish (Morgan, 1991). Similar observations were reported (Hidayat, 2004) in juvenile seabass (Lates calcarifer) also.

Glucose resulting from carbohydrate metabolism forms the primary source of energy for all metabolic processes including osmoregulation (Perry and Walsh, 1989; Morgan et al., 1997). Glycogen forms the stored carbohydrate source for all metabolic activities. In our study, liver glycogen was decreasing with increasing salinity up to $20 \pm 1 \%$. There was lower liver glycogen in fingerlings of $\mathrm{T}_{4}(20 \pm 1 \%)$. This may be due to less utilisation of stored glycogen for osmoregulation at the optimum salinity of $20 \pm 1 \%$. It is reported in rainbow trout that during its migration from freshwater to seawater, there was decrease in glycogen content (Soengas et al., 1991). In our study, fingerlings reared with salinity other than the optimum $(20 \pm 1 \%)$ exhibited high glycogen level. This may be due to the requirement of more energy for osmoregulation at other salinity levels. Studies on salinity acclimation in euryhaline fishes like Oreochromis mossambicus (Nakano et al., 1998) and Sparus aurata (Sangiao-Alvarellos et al., 2003) also reported that salinity variations affect hepatic metabolism.

Oxygen consumption rate (OCR) was found to increase with increase in salinity with maximum recorded at $15 \pm 1 \%$ and it significantly reduced for the fingerlings maintained at high salinity from $20 \pm 1$ to $35 \pm 1 \%$. In general, energy consumption is indirectly proportional with the oxygen consumption in each cell. Therefore, oxygen consumption is often used as an index of metabolism. In our study, the fingerlings maintained at $20 \pm 1 \%$ recorded lowest OCR and resulted in better growth performance. Similar result was reported in Tilapia nilotica which performed better at higher salinities up to 30\%o (Farmer and Beamish, 1969). These observations provide an indirect support for the relationship between oxygen consumption and osmotic regulation. In our study, fish reared in salinity up to $15 \pm 1 \%$ o had high OCR and thereafter at $20 \pm 1$ to $35 \pm 1 \%$ OCR was reduced. Ron et al. (1995) also reported in tilapia that, fish in seawater had significantly lower oxygen consumption rate compared to fish reared in freshwater.

The transaminase enzymes, AST and ALT are important indicators of salinity stress as there is an increase in metabolic energy used, to maintain osmoregulation. As a result of increased metabolic rate during osmoregulation, AST and ALT activity increase to compensate for the destruction of body cells (muscle and liver) through amino acid compensation and formation of protein (Ebeid et al., 2005). In our study, there was an increasing trend for AST and ALT activity in both muscle and liver with minimum activity in $\mathrm{T}_{4}$ group. This may be due to the increased metabolic rate during osmoregulation at varying salinities other than $\mathrm{T}_{4}$. Similar results were reported in seabass (Roche et al., 1989), tilapia (Vijayan et al., 1996) and yellow seabream (Sultan, 2007).

Lactate dehydrogenase, an enzyme of the glycolytic pathway converts pyruvate to lactate during anaerobic pathway resulting in stress to animals. In the present study, significantly higher and lower LDH activity in muscle was observed in fingerlings reared at $5 \pm 1 \%$ and $20 \pm 1 \%$ o respectively. This was due to the isotonic condition of the water and the body fluids of the animal which reduces LDH activity through reverse glycolysis. Fingerlings reared at other salinities spend more energy for formation of lactate with more LDH activity for maintaining the ionic balance through osmoregulation. It has been reported that during salinity fluctuations, changes in modulation of ionic and osmotic mechanism occurs which results in changes in energy metabolism (Tseng et al., 2008). Salinity fluctuation studies in Sparus aurata also reported similar results in metabolic enzymes (Sangiao- Alvarellos et al., 2003; Polakof et al., 2006).

Amino acids seem to play an important role in allowing fish to adjust to the different environmental salinities, either as energy sources or as important osmolytes for cell volume regulation (Aragao et al., 2010). Total protein concentration is a non-specific immune parameter (Magnadotti, 2006) used as the basic index for the health status of fish. In our study, fingerlings of $\mathrm{T}_{1}$ recorded significantly higher serum total protein, albumin and globulin. This was in agreement with the result of elevated 
serum or plasma protein levels reported in starved red seabream (Chryrosphrys major), black seabream (Mylio macrocephalus) and red grouper (Epinephelus akaara) exposed to low salinity environments (Woo and Murat, 1981; Woo and Wu, 1982) and silver seabream (Sparus sarba) (Luk Chun-yin, 2001). In our study, there was an overall decrease in serum total protein with increasing salinity, which was due to possible utilisation of protein for the production of metabolic energy required for homaeostasis (osmoregulation). Similar result was also reported from Channa punctatus (Padma et al., 2012).

In the present study, higher and lower serum glucose was recorded in fingerlings of $T_{1}$ and $T_{2}$ respectively. Higher glucose content in fingerlings reared at $\mathrm{T}_{1}$ resulted from stress due to more energy demand for osmoregulation at lower salinity. It has been reported in Sarotherodon melanotheron that at extreme water salinities an increase in blood glucose may be attributed to liver glycogenolysis initiated by catecholamines to meet metabolic demands for osmoregulatory tissues like gills and kidney (Lea Master et al., 1990; Sangiao-Alvarellos et al., 2003). In our study, there was an increasing trend in serum alkaline phosphatase activity with increasing salinity. This could be due to the fact that with increase in salinity, the animal spent more energy towards osmoregulation. The present result coincided with previous reports in mosquito fish that, in order to maintain the normal cell membrane transport, fishes were trying to adapt to the variations in salinity through osmoregulation (Rao et al., 2006).

From our experimental study, it was concluded that the optimum salinity for the growth of orange spotted grouper fingerlings was $20 \pm 1 \%$ in terms of WG \%, SGR and FCR. Metabolic responses of different biochemical enzymes, serum biochemical parameters and different metabolites supported the growth data. The better performance of the grouper fingerlings cultured at $20 \pm 1 \%$ was due to less metabolic energy spent for ionic regulation which resulted in better growth performance of grouper fingerlings. However, a long term study needs to be conducted with more specific metabolic parameters. Results of this study will be useful for providing information on the culture potential of orange spotted grouper in areas of varying salinity during different seasons.

\section{Acknowledgements}

The authors are thankful to Dr. A. Gopalakrishnan, Director, ICAR-CMFRI, Kochi for providing necessary facilities to carry out this experiment. We are thankful to ICAR, Govt. of India, New Delhi, for financial support.

\section{References}

Aragao, C., Costas, B., Vargas-Chacoff, L., Ruiz-Jarabo, I., Dinis, M. T. and Mancera, J. M. 2010. Changes in plasma amino acid levels in a euryhaline fish exposed to different environmental salinities. Amino Acids, 38: 311-317. DOI: 10.1007/s00726-009-0252-9.

Blaber, S. J. M. 1997. Fish and fisheries of tropical estuaries. Chapman and Hall, London, UK.

Boeuf, G. and Payan, P. 2001. How should salinity influence fish growth? Comp. Biochem. Physiol., 130(4): 411-23. DOI: 10.1016/S1532-0456 (01)00268-X.

Ebeid, T. A., Eid, T. A. and El-Habbak, M. M. 2005. Liver and kidney function parameters in avian species . Proceedings of the $3^{\text {rd }}$ International Poultry Conference, 4-7 April, 2005, Hughada, Egypt.

Enayati, A., Peyghan, R., Papahn, A. A. and Khadjeh, G. H. 2013. Study on effect of salinity level of water on electrocardiogram and some of blood serum minerals in grass carp, Ctenopharyngodon idella. Vet. Res. Forum, 4(1): 49-53.

Farmer, C. J. and Beamish, F. W. H. 1969. Oxygen consumption in Tilapia nilotica in relation with swimming speed and salinity. J. Fish. Res. Board Can., 26: 07-28.

Fazio, A., Marafioti, S., Arfuso, F., Piccione, G. and Faggio, C. 2013. Influence of different salinity on haematological and biochemical parameters of the widely cultured mullet Mugil cephalus. Mar. Freshw. Behav. Physiol., 46(4): 211-218. DOI: 10.1080/10236244.2013.817728.

Hassid, W. Z. and Abraham, S. 1957. Chemical procedures for analysis of polysaccharides. In: Colowick, S. P. and Kaplan, N. O. (Ed.), Methods in enzymology, vol. 3. Academic Press Inc., New York, USA, p. 34-50.

Herrera, M. L., Vargas-Chacoff, I., Hachero, I., Ruíz-Jarabo, A., Rodiles Navas, J. I. and Mancera, J. M. 2009. Osmoregulatory changes in wedge sole (Dicologoglossa cuneata Moreau, 1881) after acclimation to different environmental salinities. Aquac. Res., 40: 762-771. DOI: 10.1111/j.1365-2109.2008.02147.x.

Hidayat, A. S. 2004. Effect of salinity on osmoregulation capacity, feed consumption, feed efficiency and growth of juvenile seabass (Lates calcarifer Bloch). M. Sc. Thesis, Kasetsart University, Bangkok, Thailand.

Imsland, A. B., Gunnarson, S., Foss, A. and Stefansson, S. O. 2002. Gill $\mathrm{Na}+, \mathrm{K}+$ ATPase activity, plasma chloride and osmolalilty in juvenile turbot (Scophthalmus maximus) reared at different temperatures and salinities. Aquaculture, 218: 671-683. DOI: 10.1016/S0044-8486(02)00423-4.

Jobling, M. 1994. Fish bioenergetics. Chapman and Hall, London, UK, 309 pp.

Kidder III G. W., Petersen Christopher, W., Preston, R. and Tobert, L. 2006. Energetics of osmoregulation II. Water flux and osmoregulatory work in the euryhaline fish, Fundulus heteroclitus. Comp. Biochem. Physiol., 305A(4): 309-382. DOI: 10.1002/jez.a.252. 
Kucuk, S., Karul, A., Yildirim, S. and Gamsiz, K. 2013. Effects of salinity on growth and metabolism in blue tilapia (Oreochromis aureus). Afr. J. Biotechnol., 12: 2715-2721. DOI: $10.5897 / A J B 12.1296$.

Lea Master, B. R., Brach, J. A., Fujico, R. S. and Nakamura, R. M. 1990. Hematologic and blood chemistry values for Sarotherodon melanotheron and a red hybrid tilapia in freshwater and seawater. Comp. Biochem. Physiol., 97A: 525-529. DOI:10.1016/0300-9629 (90)90121-8.

Luk Chun-yin 2001. Influence of salinity on urea and ammonia metabolism in silver seabream (Sparus sarba). Masters thesis. The Chinese University of Hong Kong. Hong Kong, China.

Magnadotti, B. 2006. Innate immunity of fish (overview) Fish Shellfish Immunol., 20: 137-151. DOI:10.1016/j.fsi.2004. 09.006 .

Mommsen, T. 1998. Growth and metabolism. In: Evans, D. The physiology of fishes, $2^{\text {nd }}$ edn. CRC Press, Boca Raton, USA, $65 \mathrm{pp}$.

Morgan, J. D. and Iwama, G. K. 1991. Effects of salinity on growth, metabolism and ion regulation in juvenile rainbow and steelhead trout (Oncorhynchus mykiss) and fall chinook salmon (Oncorhynchus tshawytscha). Can. J. Fish Aquat. Sci., 48: 2083-2094. DOI: 10.1139/f91-247.

Morgan, J. D., Sakamoto, T., Grau, E. G. and Iwama, G. K. 1997. Physiological and respiratory responses of the Mozambique tilapia (Oreochromis mossambicus) to salinity acclimation. Comp. Biochem. Physiol., 117A: 391-398. DOI: 10.1016/ S0300-9629 (96)00261-7.

Morgan, J. D. 1991. Effect of salinity on survival, growth, aerobic metabolism and ion regulation in early life history stages of Pacific salmonids. M. Sc. thesis, University of British Columbia, Vancouver, USA, 90 pp.

Nakano, K., Tagawa, M., Takemura, A. and Hirano, T. 1998. Temporal changes in liver carbohydrate metabolism associated with seawater transfer in Oreochromis mossambicus. Comp. Biochem. Physiol., 119B: 721-728. DOI: 10.1016/S0305-0491 (98)00048-0.

O’Neill, B., De Raedemaecker, F., McGrath D. and Brophy, D. 2011. An experimental investigation of salinity effects on growth, development and condition in the European flounder (Platichthys flesus L.). J. Exp. Mar. Biol. Ecol., 410: 39-44. DOI: 10.1016/j.jembe.2011.10.007.

Padma, P. B., Rachel, V. and Maruthi, Y. A. 2012. Acute toxicity effect of imidacloprid insecticide on serum biochemical parameters of freshwater teleost Channa punctatus. Int. J. Integr. Sci. Innov. Technol., 1(2): 18-22. DOI: 10.15680/ ijirset.2017.0601139.

Perry, S. F. and Walsh, P. J. 1989. Metabolism of isolated fish gill cells: Contribution of epithelial chloride cells. J. Exp. Biol., 144: $507-520$
Polakof, S., Arjona, F. J., Sangiao-Alvarellos, S., Martín del Río, M. P., Mancera, J. M. and Soengas , J. L. 2006. Food deprivation alters osmoregulatory and metabolic responses to salinity acclimation in gilthead seabream Sparus auratus. J. Comp. Physiol., 176B: 441-452. https://doi.org/10.1007/ s00360-006-0065-z.

Rao, J. V., Begum, G., Jakka, N. M., Srikanth, K., Rao and R. N. 2006. Sublethal effects of profenofos on locomotor behavior and gill architecture of the mosquito fish, Gambusia affinis. Drug. Chem. Toxicol., 29: 255-267. DOI: $10.1080 / 01480540600651543$.

Roche, H., Charr, K. and Peres, G. 1989. The effect of a gradual decrease in salinity on the significant constituents of tissue in the seabass Dicentrarchus labrax. Comp Biochem. Physiol., 93A: 785-789. DOI: 10.1016/0300-9629 (89) 90502-1

Ron, B., Shimoda, S. K., Iwama, G. K. and Garu, E. G 1995. Relationships among ration, salinity, 17- $\alpha$ methyl testosterone and growth in the euryhaline tilapia, Oreochromis mossambicus. Aquaculture, 135: 185-193. DOI: 10.1016/0044-8486 (95)01013-0.

Sangiao-Alvarellos, S., Laiz-Carrion, S., Guzman, R., Martin del Rio, M. P., Miguez, J. M., Mancera, J . M. and Soengas, J. L. 2003. Acclimation of Sparus aurata to various salinities alters energy metabolism of osmoregulatory and nonosmoregulatory organs. Am. J. Physiol., 285: R897- R907. DOI: 10.1152/ajpregu.00161.2003.

Soengas, J. L., Otero, J., Fuentes, J., Andres, M. D. and Aldegunde, M. 1991. Preliminary studies on carbohydrate metabolism changes in domesticated rainbow trout (Oncorhynchus mykiss) transferred to diluted seawater (12 ppt). Comp. Biochem. Physiol., 98B: 53-57. DOI: 10.1016/0305-0491 (91)90307-Y.

Sultan, F. A. 2007. Effect of salt acclimatization on some nutritional and physiological aspects in juvenile Acanthopagrus latus. Ph. D.Thesis, College of Agriculture, University of Basrah, Iraq, 162 pp.

Tsuzuki, M. Y., Sugai, J. K., Maciel, J. C., Francisco, C. J. and Cerqueira, V. R. 2007. Survival, growth and digestive enzyme activity of juveniles of the fat snook (Centropomus parallelus) reared at different salinities. Aquaculture, 271: 319-325. DOI: 10.1016/j.aquaculture.2007.05.002.

Vijayan, M. M., Morgan, J. D., Sakamoto, T., Gran, E. G. and Iwama, G. K. 1996. Food deprivation effects on seawater acclimation in tilapia: Hormonal and metabolic changes. J. Exp. Biol., 199: 2467-2475.

Webster, J. and Dill, L. M. 2006. The energetic equivalence of changing salinity and temperature to juvenile salmon, Funct. Ecol., 20: 621-629. DOI: 10.1111/j.13652435.2006.01128.x.

Woo, N. Y. S. and Murat, J. C. 1981. Studies on the biology of red sea bream Chrysophyrys major III. Metabolic response to starvation in different salinities. Mar. Biol., 6: 255-260. DOI: $10.1007 / \mathrm{BF} 00386668$.

Woo, N. Y. S. and Wu, R. S. S. 1982. Metabolic and osmoregulatory changes in response to reduced salinities 
in the red grouper, Epinephelus akaara (Temminck and Schlegel) and the black seabream Mylio macrocephalus (Basilewsky). J. Exp. Mar. Biol. Ecol., 65: 139-161. DOI: 10.1016/0022-0981(82)90041-7.

Wootton, I. D. P. 1964. Enzymes in blood. In: Churchill, J. and Churchill, A. (Eds.), Microanalysis in medical biochemistry, $4^{\text {th }}$ edn. Churchill, London, UK, p 101-107.
Wroblewski, L. and Ladue, J. S. 1955. LDH activity in blood. Proc. Soc. Exp. Biol. Med., 90: 210-213. DOI: 10.3181/00379727-90-21985.

Tseng, Y. C., Lee J. R., Chang, J. C . H., Kuo, C. H., Lee, S. J. and Hwang, P. P. 2008. Regulation of lactate dehydrogenase in tilapia (Oreochromis mossambicus) gills during acclimation to salinity challenge. Zool. Stud., 47(4): 473-480. 